Vol. 5 (1), pp. 010-019, March, 2015

ISSN: 2276-7762; ICV: 5.99

Copyright $@ 2015$, the copyright of this article is retained by the author(s)

DOI Link: http://doi.org/10.15580/GJBS.2015.1.012115007

http://gjournals.org/GJBS

\title{
Detection of Aminoglycoside Modifying Enzymes and $\beta$-lactamases in Acinetobacter baumannii Isolated from Hospitalized Iraqi Patients
}

\section{ISRAA Mohamed Safi Al-kadmy ${ }^{1}$, MARWAH Hasan Al-Kaabi ${ }^{2}$, HADEEL Kareem Musafer ${ }^{1}$}

${ }^{1}$ Department of Biology, College of Science, University of Mustansiriya, Baghdad 14022, Iraq. ${ }^{2}$ National center of Hematology, University of Mustansiriya, Baghdad, Iraq.

\section{ARTICLE INFO}

\section{ABSTRACT}

Article No.: 012115007

Type: Research

DOI: 10.15580/GJBS.2015.1.012115007

Submitted: $21 / 01 / 2015$

Published: 28/03/2015

${ }^{*}$ Corresponding Author

Israa Mohamed Safi Al-kadmy

E-mail: israaalkadmy @gmail.com

Keywords:

Aminoglycoside modifying enzymes, Acinetobacter baumannii, Iraq
Background/aim: Acinetobacter baumannii is one of the most commonly encountered as multiresistance microorganism. This study was designated for investigating of $\beta$-lactamases resistance genes and aminoglycosides modifying enzymes (AMEs) in Acinetobacter baumannii isolated from Iraqi patients.

Materials and methods: A total of 36 A. baumannii isolates were recovered from hospitalized Iraqi patients during May to September 2012. Antibiotic susceptibility test was performed against aminoglycosides antibiotics and phenotypic detection of B-lactamases was done using Extended Spectrum Beta Lacatmases (ES $\beta L$ ) strip. Polymerase Chain Reaction (PCR) amplification was achieved for investigating $\beta$-lactamases genes (blasHV, bla TEM, and bla $_{C T X}$ ) and aminoglycosides modifying enzymes (aac(6)-Ib, ant(4')-IIb, aa(c) 3' and aph(3')-VI).

Results: Out of 36 A. baumannii isolates, $15(41.66 \%)$ were resistant to aminoglycosides antibiotics according to disk diffusion method. 17 (47.22\%) isolates gave positive results in the preliminary screening of $\beta$-lactamases, the ES $\beta$ Ls type and AmpC enzyme, while $13(36.11 \%)$ of the isolates gave a positive result in Metallo- $\beta$ - lactamases production test. PCR analysis demonstrated that blatem was detected in $3(20 \%)$ of the resistant isolates, blashv was detected in 9 $(60 \%)$, blaстх-м was detected in 11 (73.33\%), aac (6)-lb was detected in 7 (46.66\%), ant(4')-IIb was detected in 5(33.33\%), aph(3')-VI in $2(13.33 \%)$, and aa(c) $3^{\prime}$ was found in $10(66.66 \%)$ of the resistant isolates.

Conclusion: Local $A$. baumannii isolates with AMEs and $\beta$-lactamases genes represent a powerful nosocomial pathogen that threat the antibiotic era and life of immunocompromied and hospitalizes patients and this should be taken into account to find a new ways for the restriction of these powerful pathogens. 


\section{INTRODUCTION}

Acinetobacter baumannii is an emerging pathogen responsible for causing a wide range of nosocomial infections, including pneumonia, urinary tract infections, and septicemia particularly in immunocompromied patients (Karlowsky et al., 2003). Due to its outstanding ability to upregulate or attain resistance determinants and its environmental flexibility, it's considered one of the most microbial threat to the antibiotic treatment strategy (Nordmann, 2004).

Recently multi-drug resistant $A$. baumannii strains have now been reported, signifying a sentinel event that should be acted on promptly by the international health care community (Hussein et al., 2013). Extensive use of antimicrobial chemotherapy within hospitals has contributed to the emergence and procreation of $A$. baumannii strains which are resistant to a wide range of antibiotics, including broad spectrum $\beta$ lactams, aminoglycosides, and fluoroquinolones (Asadollahi et al., 2012). Resistance to $\beta$-lactams appears to be primarily caused by $\beta$-lactamase production, including the extended spectrum $\beta$ lactamases (blatem, blashv, blaveB, blaper), metallo- $\beta$ lactamases (blaımp, blavıм, blasıм, blagın), and most commonly, oxacillinases (blaoxa51, 23, 24 and 58), while the resistance to aminoglycosides may be through many known mechanisms but the enzymatic modification is the most prevalent in the clinical setting (Asadollahi et al., 2012).

Aminoglycoside modifying enzymes (AMEs) catalyze the modification at different $-\mathrm{OH}$ or $-\mathrm{NH}_{2}$ groups of the 2-deoxystreptamine nucleus or the sugar moieties and can be nucleotidyltranferases, phosphotransferases, or acetyltransferases (Ramirez and Tolmasky, 2010). Thus, there are three types of these enzymes: Aminoglycoside N-Acetyltransferases (AACs), Aminoglycoside O-Nucleotidyltransferases (ANTs), Aminoglycoside O-Phosphotransferases (APHs). The AAC family of enzymes is composed of four major subclasses based on region specificity of aminoglycoside acetyltransfer: $\mathrm{AAC}\left(6^{\prime}\right), \quad \mathrm{AAC}\left(2^{\prime}\right)$, $A A C(1)$, and $A A C(3)$, while there are five members of the ANT family of enzymes, ANT( $\left.2^{\prime \prime}\right)$, ANT( $\left.4^{\prime}\right)$, ANT( $\left(3^{\prime}\right)$, ANT $\left(6^{\prime}\right)$ and ANT(9) (Arya, 2007). The third mechanism of aminoglycoside modification is ATP-dependent phosphorylation of key hydroxyl groups, a reaction catalyzed by the APH family of kinases including $\mathrm{APH}\left(2^{\prime \prime}\right), \mathrm{APH}\left(3^{\prime}\right), \mathrm{APH}\left(3^{\prime \prime}\right), \mathrm{APH}\left(7^{\prime \prime}\right), \mathrm{APH}(4), \mathrm{APH}(6)$, and $\mathrm{APH}(9)$ (Arya, 2007). Aminoglycoside-modifying enzymes have become widespread throughout bacterial communities because many of the encoding genes are found on mobile genetic elements such as integrons, transposons, and plasmids, thus facilitating horizontal gene transfer (Arya, 2007). The emergence of aminoglycoside-inactivating enzymes has contributed to the diminished use of several aminoglycoside antibiotics and the presence of these types of enzymes have been found in $A$. baumannii, often occurring in combination (Arya, 2007, Seward et al., 1998).

Some reports referred to the presence of these types of enzymes in Iraq, especially the studies that were done on the military and civilian casualties from the Iraqi conflict and some genes responsible for Aminoglycoside modifying enzymes were detected, e.g: aacC1, aadA1a, aadB, aacA4, and aadA1 (Turton et al., 2005). So this study aimed for the detection of other types of AMEs genes besides some of $\beta$-lactamases resistance genes in some of $A$. baumannii that have been isolated from hospitalized patients in Iraq.

\section{MATERIAL AND METHODS}

\section{Bacterial strains and identification}

A total of 36 A. baumannii isolates were recovered form hospitalized patients during the period from May to September 2012. The isolates were collected from different sites including: sputum (one isolate), cerebrospinal fluid (one isolate), urine (17 isolates), wounds (17 isolates), and blood ( 6 isolates). All these isolates were identified according to morphological features and biochemical tests. What's more, identification was confirmed using the api20E system.

\section{Antibiotic susceptibility test}

Antibiotic susceptibility for $A$. baumannii isolates was performed against aminoglycosides antibiotics including: amikacin $(30 \mu \mathrm{g})$, gentamicin $(30 \mu \mathrm{g})$, netilmicin $(30 \mu \mathrm{g})$, tobramycin $(10 \mu \mathrm{g})$, and sisomycine $(10 \mu \mathrm{g})$ (Bioanalyse, Turkey) using disc diffusion method in accordance with the guidelines established by the Clinical and Laboratory Standard Institute (CLSI, 2013) . Escherichia coli (E. coli ATCC 25922) was used as a quality control in susceptibility determination.

\section{Rapid detection of ES $\beta$ L production via ES $\beta$ L strip:}

The detection of $\beta$-lactamases production was performed using Rapid ES $\beta$ L Detection kit (MAST Group (UK). This kit includes four tests: Preliminary screening kit, Metallo $\beta$ lactamases, ES $\beta$ Ls confirmation and AmpC detection. The test was performed according to the procedure suggested by the manufacturing company: first, primary screening test to detect $\beta$ lactams resistance was performed by culturing bacterial isolates on appropriate medium with cefotaxime 30 $\mu \mathrm{g} / \mathrm{disc}$. The resisted isolates were submitted to $E S \beta L$ production test. One drop of test substrate (approximately $20 \mu \mathrm{l}$ ) was dispensed on the filter pad of the strip. The test substrate was added immediately to the strip before testing. Using a loop, several identical colonies were picked up and spread on the filter pad of the test strip. Any change in color (from yellow to red) 
observed around the streaked line was considered as a positive result. The tested strips were observed after 2 to 15 minutes at room temperature, and the result was read after 15 minutes.

\section{DNA Preparation and Polymerase Chain Reaction (PCR) amplification:}

Total genomic DNA was extracted by boiling according to the method described by Ruppé et al. (2009). Briefly, few isolated colonies of overnight growth bacteria were suspended thoroughly in $1 \mathrm{ml}$ distilled water and boiled in a water bath for $10 \mathrm{~min}$. After centrifugation, supernatant was used as template DNA for the PCR (Ruppé et al., 2009). PCR was performed using primers specific for $\beta$-lactamases enzymes families (blasHV, bla TEM $_{\text {, bla }}$ (T) and aminoglycosides modifying enzymes ( $a a c(6)-l b$, ant (4')-IIb, aa(c) $3^{\prime}$ and $\left.a p h\left(3^{\prime}\right)-\mathrm{VI}\right)$. The oligonucleotide PCR primers specific for the target genes, annealing temperature and sizes of the expected amplification product were listed in Table 1.

The PCR reaction mixture was accomplished according to the procedure suggested by the manufacture company (KAPA, south Africa) within a total volume of $25 \mu \mathrm{l}$ containing $5 \mu \mathrm{l}$ of DNA template, $12.5 \mu \mathrm{l}$ of Go Taq ${ }^{\circledR}$ Green Master Mix, 2X (KAPA, south Africa), $0.5 \mu \mathrm{l}(0.6 \mathrm{pmol})$ of each of the forward and the reverse of the specific primers. The final volume $(25 \mu \mathrm{l})$ was completed with $6.5 \mu \mathrm{l}$ of nuclease free water. The conditions of PCR amplification steps was carried out using the thermal cycler (C 1000 thermal cycler, BIORAD, USA) and the amplified PCR products were submitted to electrophoresis using $1 \%$ agarose gel with ethidium bromide $(0.5 \mu \mathrm{g} / \mathrm{ml})$ for $7 \mathrm{~V} / \mathrm{cm}$ for $90 \mathrm{~min}$. DNA ladder (100bp) was employed for assessing PCR product size. Subsequently, PCR products were visualized by UV light at $336 \mathrm{~nm}$, and photographs were taken by an aid of digital camera.

Table (1): The oligonucleotide PCR primers specific for the target genes, annealing temperature and sizes of the expected amplification product

\begin{tabular}{|c|c|c|c|c|}
\hline Gene & $\begin{array}{c}\text { Sequence of forward and reverse } \\
\text { Primer }\left(5^{\prime} \rightarrow 3^{\prime}\right)\end{array}$ & $\begin{array}{c}\text { Annealing } \\
\text { temperature }\left({ }^{\circ} \mathrm{C}\right)\end{array}$ & $\begin{array}{c}\text { Size } \\
\text { product }\end{array}$ & Reference \\
\hline blasHV & $\begin{array}{l}\text { F- AAGATCCACTATCGCCAGCAG } \\
\text { R- ATTCAGTTCCGTTTCCCAGCGG }\end{array}$ & 59 & 200bp & $\begin{array}{l}\text { [Oliveira } \\
\text { et al., } \\
2011 \text { ] }\end{array}$ \\
\hline bla ${ }_{C T X-M}$ & $\begin{array}{l}\text { F-CGCTTTGCGATGTGAAG } \\
\text { R-ACCGCGATATCGTTGGT }\end{array}$ & 55 & 550bp & $\begin{array}{l}\text { [Oliveira } \\
\text { et al., } \\
2011]\end{array}$ \\
\hline bla $_{T E M}$ & $\begin{array}{l}\text { F-GAGTATTCAACATTTCCGTGTC } \\
\text { R-TAATCAGAGGCACCTATCTC }\end{array}$ & 48 & 800bp & $\begin{array}{l}\text { [Oliveira } \\
\text { et al., } \\
2011 \text { ] }\end{array}$ \\
\hline$a a c(3)-1$ & $\begin{array}{l}\text { F- AGCCCGCATGGATTTGA } \\
\text { R- GGCATACGGGAAGAAGT }\end{array}$ & 43 & 227 & $\begin{array}{l}\text { [Ndegwa } \\
\text { et al., } \\
\text { 2012] }\end{array}$ \\
\hline $\begin{array}{l}\text { aac(6)- } \\
\quad l b\end{array}$ & $\begin{array}{l}\text { F- TTG CGA TGC TCT ATG AGT GGC TA } \\
\text { R- CTC GAA TGC CTG GCG TGT TT }\end{array}$ & 56 & 482 & $\begin{array}{l}\text { [Haldorsen } \\
\text {,2011] }\end{array}$ \\
\hline$a n t\left(4^{\prime}\right) \| l b$ & $\begin{array}{l}\text { F- GACGACGACAAGGATATGGAATTGCCCAAT } \\
\text { ATTATT } \\
\text { R- GGAACAAGACCCGTTCAATTCAATTCATC } \\
\text { AAGTTT }\end{array}$ & 57 & 364 & $\begin{array}{l}\text { [Haldorsen } \\
\text {, 2011] }\end{array}$ \\
\hline $\begin{array}{c}\operatorname{aph}\left(3^{\prime}\right) V \\
I\end{array}$ & $\begin{array}{l}\text { F- TAT CTC GGC GGC GGT CGA GT } \\
\text { R- CAC GCG GGG AAA CGC GAG AA }\end{array}$ & 55 & 800 & $\begin{array}{l}\text { [Vaziri et } \\
\text { al., 2011] }\end{array}$ \\
\hline
\end{tabular}

\section{RESULTS}

\section{Morphological and biochemical characterization}

All clinical isolates obtained from various clinical specimens identified as $A$. baumannii based on their morphological and biochemical characterization.

\section{Antibiotic resistance pattern}

The aminoglycosides susceptibility results are depicted in Figure 1. Accordingly, 15 (41.66\%) A. baumannii isolates were found to be resistant to the tested antibiotics.

Regarding to the source of the infection, high resistance rate was observed among the wound isolates which were completely resistance $(100 \%)$ to gentamicin and sisomycine. Furthermore, they showed high resistance rate $(72.72 \%)$ to tobramycin and intermediate resistance to netilmicin (54.54\%) and amikacin 
(45.45\%). On contrary, all urine isolates were sensitive to all antibiotic under investigation. For the blood isolates, results revealed a high sensitivity to aminoglycosides; amikacin and netilmicin (100\%) and $83.44 \%$ for gentamicin, tobramycin, and sisomycine. While the sputum and the Cerebrospinal fluid isolates were completely sensitive to all the antibiotics except for the amikacin in which the sputum isolates were sensitive to this antibiotic.

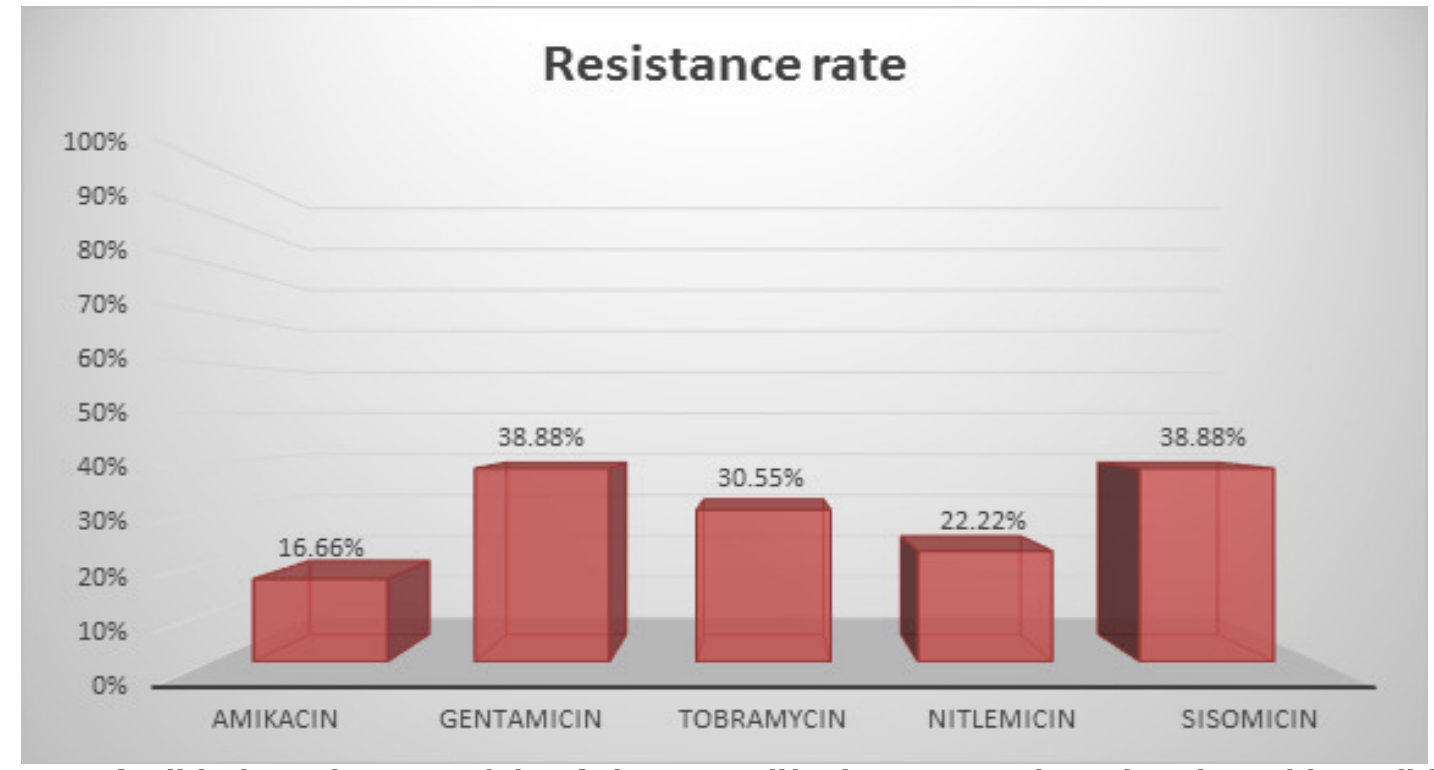

Figure 1: Antibiotic resistance of the A. baumannii isolates towards aminoglycoside antibiotic

\section{Detection of ES $\beta L$ Production}

The investigation of $\beta$-lactamases production was carried out using ES $\beta$ L strips. According to this test, 17 $(47.22 \%)$ isolates gave positive results in the preliminary screening of $\beta$-lactamases, the ES $\beta$ Ls type and AmpC enzyme while $13(36.11 \%)$ isolates showed a positive result in Metallo- $\beta$ - lactamases production test. Figure 2 illustrates the results for one isolates, $A$. baumannii (no. 10 ) in which red color appeared with the first strip (A no.1) for preliminary screening after addition of specific inhibitors, while the second stripe (A no. 2) represents a positive result for ESBLs after the addition of Clavulanic Acid, the third positive result (A no.3) for $M \beta L$ strip with red color appeared after the addition of EDTA and Mercaptoacetic acid and finally the $4^{\text {th }}$ strip (A no.4) signifies AmpC strip which appeared red color after the addition of Boronic Acid. No change occurred with the negative control represented by the standard strain $E$. coli ATCC 25922 in the Figure (2) which clearly appeared as a yellow color.

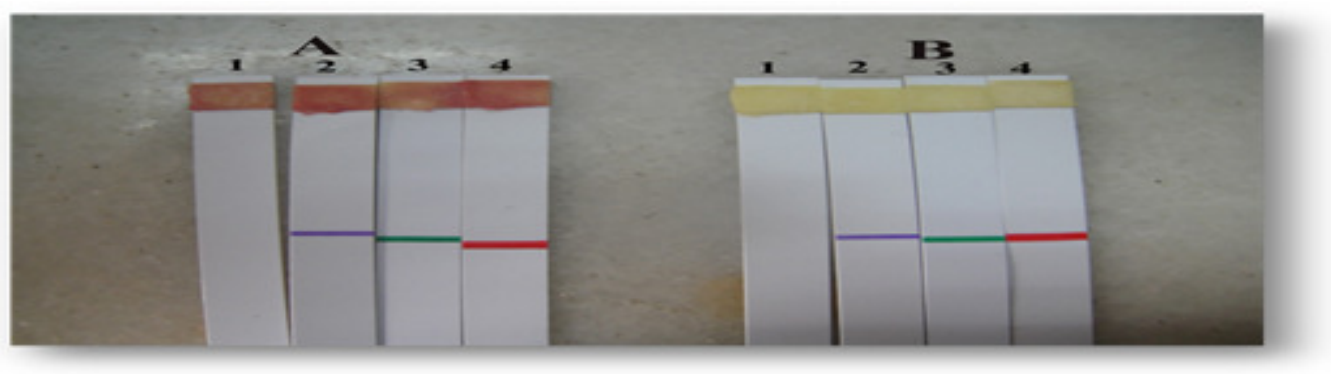

Figure 2: Detection of $\beta$-lactemase types using easy strips test. A-1:positive result for primary screening test of E.coli no. 10. A-2: positive result for ES $\beta$ Ls of $A$. baumannii no.10. A-3: positive result for M $\beta L$ of $A$. baumannii no.10. A-4: positive result for AmpC of $A$. baumannii no.10. B 1-4: negative result for all above tests of the standard strain E. coli ATCC 25922 


\section{PCR analysis}

The prevalence of $\beta$-lactamas and aminoglycoside resistance genes in 15 resistant $A$. baumannii isolates (as determined by the disk diffusion method) was as follows: blateм was detected in $3(20 \%)$ isolates, blashv was detected in $9(60 \%)$ isolates, blacтх-м was detected in 11 (73.33\%) isolates, aac (6)-Ib in 7 (46.66\%) isolates, ant $\left(4^{\prime}\right)-I I b$ in 5 (33.33\%) isolates, aph(3)-VI in 2 $(13.33 \%)$ isolates, and aa(c) $3^{\prime}$ was found in $10(66.66 \%)$ isolates (Figure $3,4,5,6,7,8,9$ ). Interestingly, individual aminoglycoside-resistant isolates carried multiple (two to six) $\beta$-lactamases and modifying enzyme genes. Table 2 demonstrates the distribution of these genes in the $A$. baumannii isolates.

Table (2): the distribution of these genes among the $A$. baumannii isolates

\begin{tabular}{|c|c|c|}
\hline $\begin{array}{l}\text { A. baumannii } \\
\text { isolates }\end{array}$ & Resistance profile & Resistance genotype \\
\hline Aw10 & GEN +SIS & $\mathrm{SHV}+a a(c) 3^{\prime}$ \\
\hline Aw11 & GEN +SIS & $a a(c) 3^{\prime}$ \\
\hline Ab12 & GEN +SIS & $C T X+a a(c) 3^{\prime}$ \\
\hline Aw 14 & GEN +SIS & $\mathrm{SHV}+a a(c) 3^{\prime}$ \\
\hline $\mathrm{Ab} 15$ & TOB & $\begin{array}{c}S H V+C T X+a a c(6)-I b+a n t\left(4^{\prime}\right)-I l b+a a(c) \\
3^{\prime}\end{array}$ \\
\hline As19 & GEN + TOB + NTil +SIS & $\mathrm{CTX}+a n t\left(4^{\prime}\right)-I I b+a a(c) 3^{\prime}$ \\
\hline Aw 20 & $\mathrm{GEN}+\mathrm{TOB}+\mathrm{SIS}$ & SHV + CTX + ant(4')-IIb+aa(c) $3^{\prime}$ \\
\hline Aw 21 & $\mathrm{AKN}+\mathrm{GEN}+\mathrm{TOB}+\mathrm{NTil}+\mathrm{SIS}$ & $\mathrm{CTX}+\operatorname{aac}(6)-1 \mathrm{~b}$ \\
\hline Aw 22 & $\mathrm{AKN}+\mathrm{GEN}+\mathrm{TOB}+\mathrm{NTil}+\mathrm{SIS}$ & $S H V+C T X+a a c(6)-I b$ \\
\hline Aw 23 & $\mathrm{AKN}+\mathrm{GEN}+\mathrm{TOB}+\mathrm{NTil}+\mathrm{SIS}$ & $\begin{array}{c}S H V+C T X+a a c(6)-l b+a n t\left(4^{\prime}\right)-I I b+ \\
a p h\left(3^{\prime}\right)-V I+a a(c) 3^{\prime}\end{array}$ \\
\hline Aw24 & $\mathrm{AKN}+\mathrm{GEN}+\mathrm{TOB}+\mathrm{NTil}+\mathrm{SIS}$ & TEM + CTX \\
\hline Aw25 & GEN + TOB + NTil +SIS & $\mathrm{TEM}+\mathrm{SHV}+\mathrm{CTX}+a a c(6)-I b$ \\
\hline Aw 32 & $\mathrm{AKN}+\mathrm{GEN}+\mathrm{TOB}+\mathrm{NTil}+\mathrm{SIS}$ & $\begin{array}{c}\mathrm{SHV}+\mathrm{CTX}+\operatorname{aac}(6)-\mathrm{Ib}+a p h\left(3^{\prime}\right)-\mathrm{VI}+ \\
a a(c) 3^{\prime}\end{array}$ \\
\hline Aw 33 & GEN + TOB + NTil +SIS & TEM + SHV \\
\hline Ac 36 & $\mathrm{AKN}+\mathrm{GEN}+\mathrm{TOB}+\mathrm{NTil}+\mathrm{SIS}$ & $C T X+a a c(6)-I b+a n t\left(4^{\prime}\right)-I l b+a a(c) 3^{\prime}$ \\
\hline
\end{tabular}

Aw: A. baumannii isolated from wound, Ab: A. baumannii isolated from blood, As: A. baumannii isolated from sputum Ac : A. baumannii isolated from, AKN : amikacin, GEN : gentamicin, TOB : tobramycin, NTil : netilmicin, SIS: sisomycine.

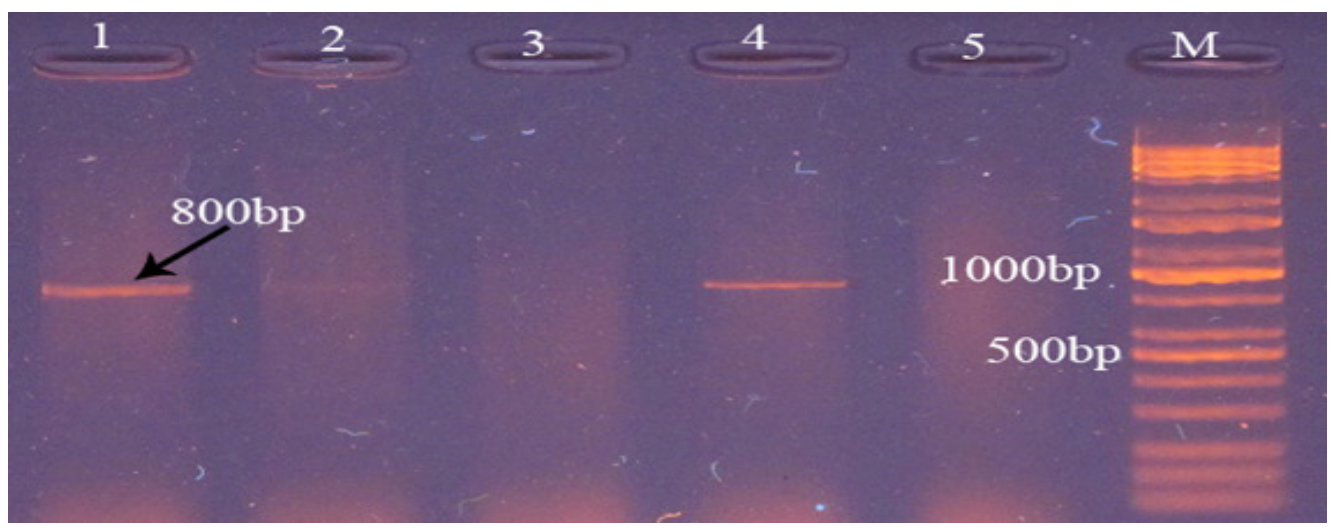

Figure 3: Gel electrophoresis (1\% agarose, $7 \mathrm{~V} / \mathrm{cm}$ for $90 \mathrm{~min}$ ) for bla TEM gene for some $A$. baumannii isolates. Line M 100bp DNA ladder, lines $(1,4)$ positive results with $800 \mathrm{bp}$ amplicon 


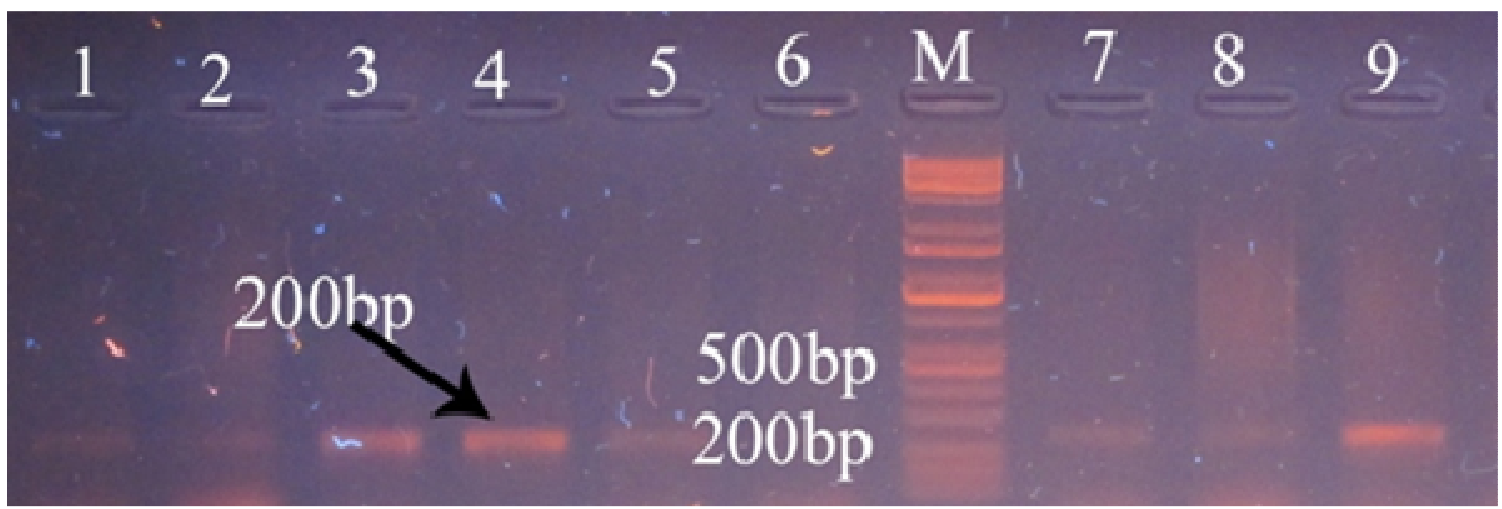

Figure 4: Gel electrophoresis (1\% agarose, $7 \mathrm{~V} / \mathrm{cm}$ for $90 \mathrm{~min}$ ) for bla SHV gene for some $A$. baumannii isolates. line M 100bp DNA ladder, lines $(1,2,3,4,5,7,8,9)$ positive results with $200 \mathrm{bp}$ amplicon

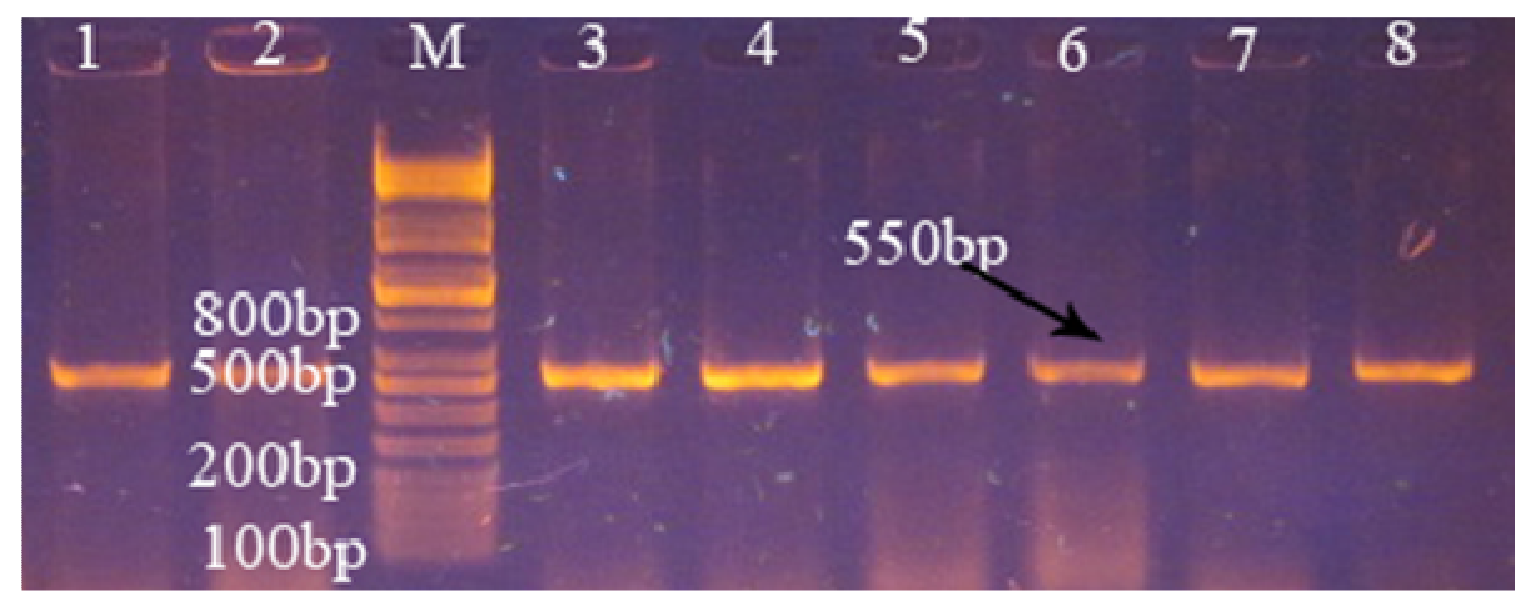

Figure 5: Gel electrophoresis (1\% agarose, $7 \mathrm{~V} / \mathrm{cm}$ for $90 \mathrm{~min}$ ) for blaCTX-M gene for some $A$. baumannii isolates. Line M 100bp DNA ladder, lines $(1,2,3,4,5,6,7,8)$ positive results with $550 \mathrm{bp}$ amplicon

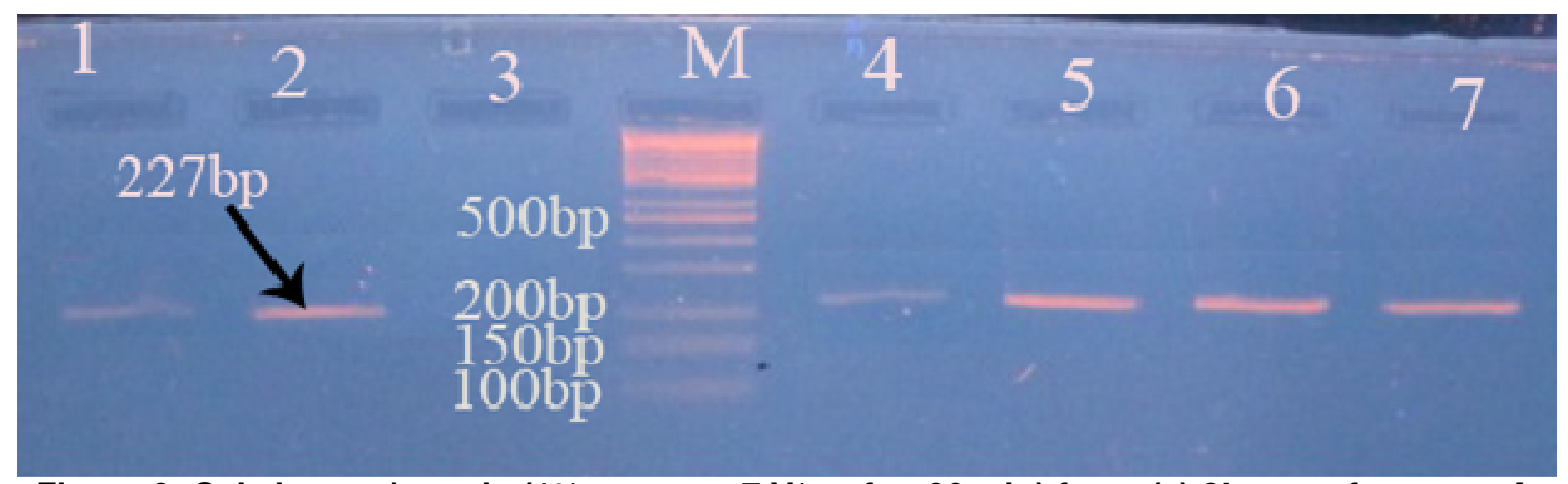

Figure 6: Gel electrophoresis (1\% agarose, $7 \mathrm{~V} / \mathrm{cm}$ for $90 \mathrm{~min}$ ) for aa(c) $3^{\prime}$ gene for some $A$. baumannii isolates. Line M 100bp DNA ladder, lines $(1,2,4,5,6,7)$ positive results with 227 bp amplicon 


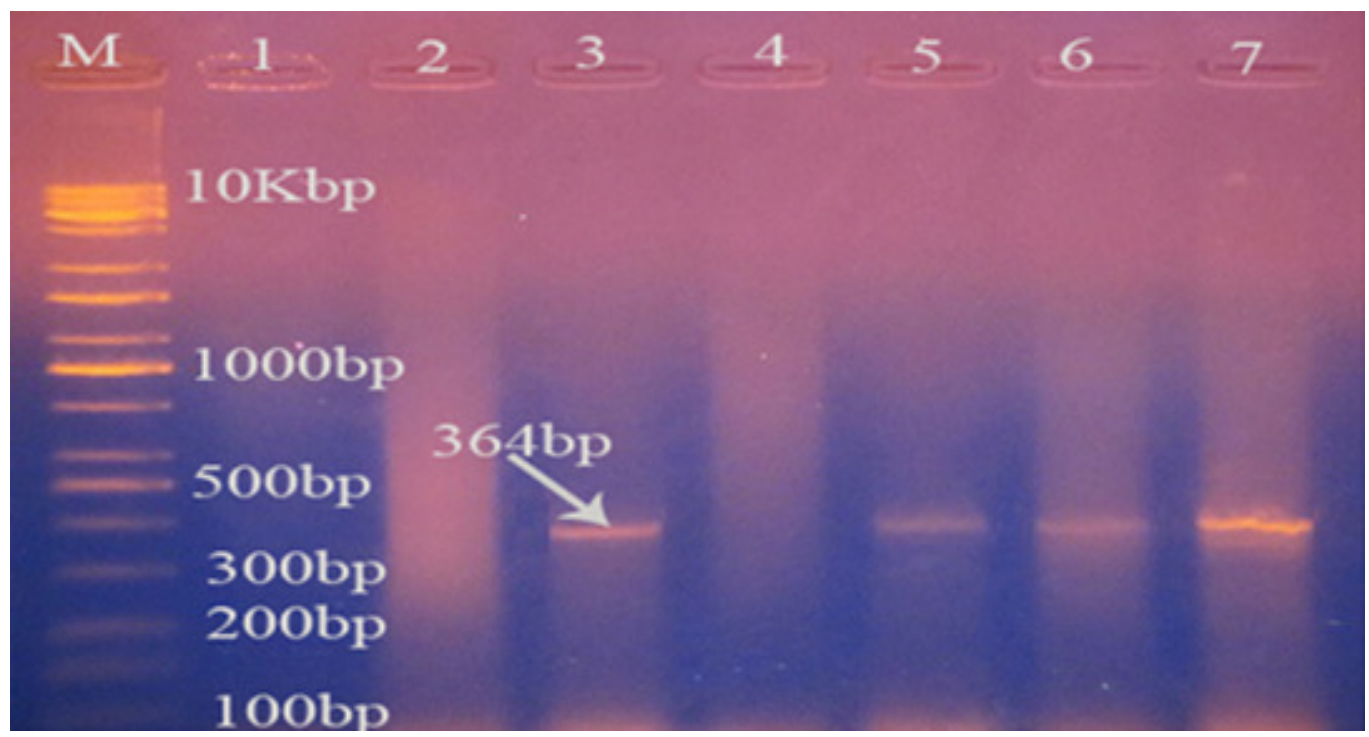

Figure 7: Gel electrophoresis (1\% agarose, $7 \mathrm{~V} / \mathrm{cm}$ for $90 \mathrm{~min}$ ) for ant(4')-Ilb gene for some $A$. baumannii isolates. Line M 100bp DNA ladder, lines $(3,5,6,7)$ positive results with $364 \mathrm{bp}$ amplicon

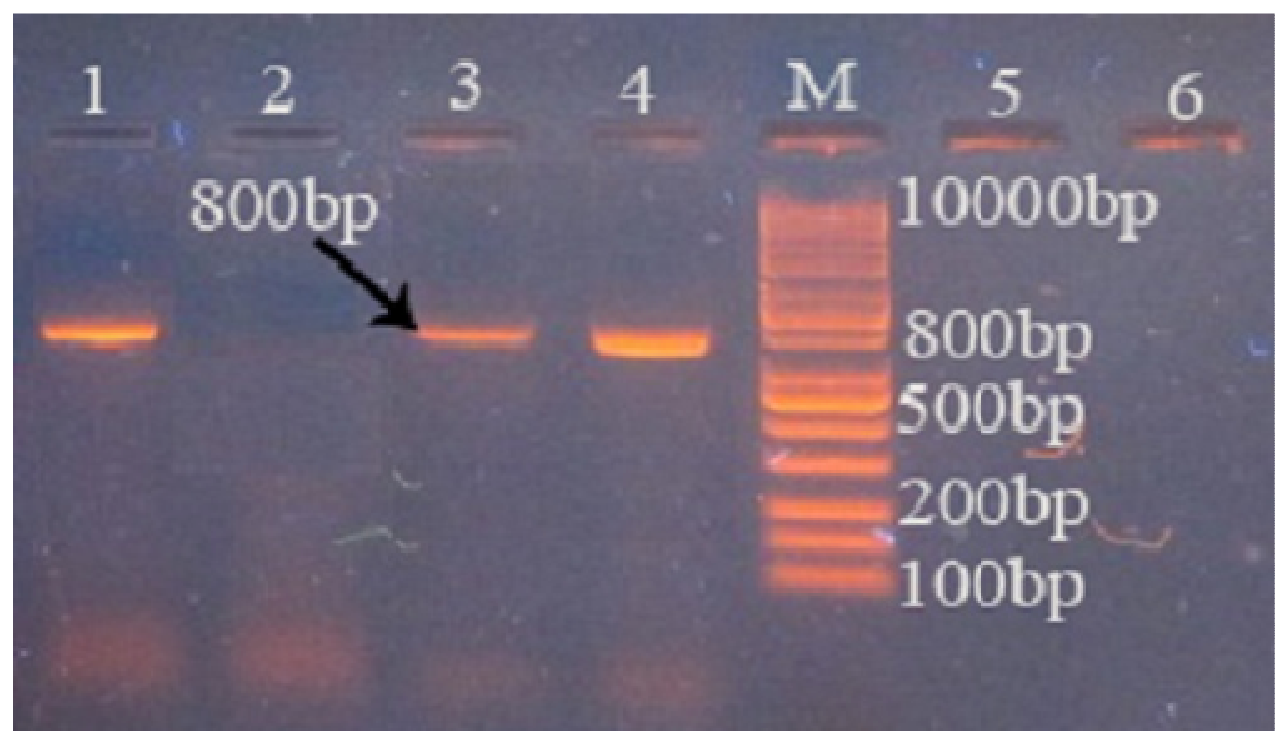

Figure 8: Gel electrophoresis ( $1 \%$ agarose, $7 \mathrm{~V} / \mathrm{cm}$ for $90 \mathrm{~min}$ ) for aph(3')-VI gene for some $A$. baumannii isolates. Line M 100bp DNA ladder, lines $(1,3,4)$ positive results with $800 \mathrm{bp}$ amplicon

\section{DISCUSSION}

The present study describes the emergence and spread of $\beta$-lactamases and aminoglycoside resistant $A$. baumannii isolates in Baghdad, Iraq. Antibiotic resistance and genetic features were investigated. Remarkably, most isolates of $A$. baumannii were obtained from urine and wound specimens. The result of susceptibility for all $A$. baumannii isolates to aminoglycosides group revealed that Amikacin had the best efficacy against these isolates, given that only $16.66 \%$ of total isolates developed resistance. Dent et al. (2010) and $\mathrm{Xu}$ et al. (2012) found that resistance rate to Amikacin reached $56 \%, 58 \%$ and $53.7 \%$, respectively. The resistance rate of gentamicin antibiotic was $38.88 \%$, this results was in accordance with the result of Wei-feug et al. (2005) in which they found that $48.6 \%$ of the isolates were resistance. Hassan et al. (2010) reported that $28 \%$ of $A$. baumannii Pakistani isolates were resistant to tobramycin. Such finding goes with 
ours. Nonetheless, Moniri et al. (2010) stated that the resistance rate to tobramycin was $68.3 \%$. Whereas, the resistance rate of netilmicin reached $22.22 \%$ which is lower than what Jaggi et al. (2012) indicated, as they recorded $90.3 \%$ of the isolates were resistance.

\section{Rapid detection of ES $\beta L$ production via ES $\beta L$ strip}

Since there are no standard guidelines for the detection of MBL, different studies have reported the use of various methods (Jaggi et al., 2012). In the current study four types of $\beta$-lactamases were detected including: preliminary screening for $\beta$-lactemase, ES $\beta$ Ls type, Metallo- $\beta$ - lactamases and AmpC enzyme. About half of the $A$. baumannii isolates (47.22\%) were able to produce $\beta$-lactamases, this result was in a good agreement with the result of Trivedi et al., (2012) in which they found that $60 \%$ of the isolates were $\beta$ lactemase producer. In our study, all of the $\beta$-lactemase producing $A$. baumannii isolates were found to be ES $\beta$ LS and AmpC producer (47.22\%). However, a disagreement was noticed, as they found that only $10 \%$ of the isolates were ES $\beta$ Ls producer and $20 \%$ of the isolates were AmpC producer.

In our study, Metallo- $\beta$-lactamases was detected in $36.11 \%$ of the A.baumannii isolates. Many previously studies reported Metallo- $\beta$-lactamases production in $A$. baumannii (Gupta et al., 2006; Ahir et al., 2012; Daef et al., 2012). An Indian study on the $A$. baumanii species stated a significant increase $(70.9 \%)$ in Metallo- $\beta$ lactamases production which is much higher than our findings (Uma et al., 2009), while another study reported from Kerala, India, states that $21 \%$ of the $A$. baumannii isolates were found to be metallo- $\beta$-lactamase producers which is similar to our finding (Kumar et al., 2011). Another study from India demonstrated that $66.8 \%$ of the isolates were harboring Metallo- $\beta$-lactamases enzymes (Chaudhary and Payasi, 2012).

Although there are many methods for the phenotypic detection of $\beta$-lactamases enzymes (Drieux et al., 2008), we found that ES $\beta$ L strip is a new advanced method for detecting the types of $\beta$ lactemase. It is easy to perform highly specific besides; different types of enzymes could be detected in the same run.

\section{PCR analysis:}

In this study two types of resistance genes were investigated in the $A$. baumanii isolates using PCR technique which they are specific for $\beta$-lactam and aminoglycoside resistance. Among these resistance genes, the blactx was the most frequent resistance genes and detected in $13(73.33 \%)$ of the A. baumanii isolates, while the $a p h\left(3^{\prime}\right)-\mathrm{VI}$ was detected in only 2 $(13.33 \%)$ isolates.

The other genes (TEM, SHV, aac (6)-Ib, ant(4')$\mathrm{Ilb}$, and aa(c) 3' ) were detected in $20 \%, 60 \%, 46.66 \%$, $33.33 \%$ and $66.66 \%$ respectively. This finding was not similar to the finding of Huang et al. (2012) in which they found that aac (6)- Ib, aph(3)-VI and aa(c) 3' genes were detected in $20 \%, 1.25 \%$ and $47.50 \%$ respectively.

By observing the result in Table 2, we find that most of the resistance $A$. baumanii isolates were harboring more than one gene $(40 \%$ were harboring 2 genes, $20 \%$ were harboring 4 genes, $13.33 \%$ were harboring 3 and 5 genes; while $6.66 \%$ were harboring 6 and one gene). In $80 \%$ of the $A$. baumanii resistance isolates, most of these genes belonging to both $\beta$ lactamases and aminoglycoside modifying genes and this indicates the prevalence of multidrug resistance patterns among the $A$. baumanii isolates.

Multidrug resistance patterns in $A$. baumanii have been described previously in many studies done in different hospitals worldwide (Koo et al., 2010), this increase in MDR $A$. baumanii is a frightening reality (Livermore, 2003), and has given rise to significant therapeutic challenges in the treatment of nosocomial infections (Koo et al., 2010). In a recent study which was done by Taitt et al. (2014) on clinical $A$. baumannii isolates collected from military treatment facilities (MTFs) they found that $80 \%$ of the isolates were found to be MDR and this is similar to our finding. Among these resistance isolates, 2 isolates that were highly resistance to aminoglycoside antibiotic discs were harboring only the $\beta$-lactamases resistance genes (TEM, CTX and SHV) and no one of the aminoglycoside modifying enzymes were detected in spite of they were resistance to aminoglycoside, this is maybe due to that these isolates harbor another types of modification enzymes which were out of this study.

As a conclusion, $A$. baumannii isolates with AMEs and $\beta$-lactamases resistance genes represent a powerful nosocomial pathogen that threat the antibiotic area and life's of immunocompromied and hospitalizes patients and this should be take in to account to find a new ways for restriction of these powerful pathogens.

\section{REFERENCES}

Ahir HR, Patel PH, Berry RA, Parmar R, Soni ST, Shah PK et al. (2012). prevalence of metallo- $\beta$ lactamases Pseudomonas and Acinetobacter species in tertiary care teaching hospital, Gujarat. Int J Microbiol Res.4:322-5.

Arya DP (2007). Aminoglycoside antibiotics. From chemical biology to drug discovery. 2nd ed. John Wiley \& Sons, Inc., Hoboken. New Jersey.USA.

Asadollahi $\mathrm{P}$, Akbari $\mathrm{M}$, Soroush $\mathrm{S}$, Taherikalani $\mathrm{M}$, Asadollahi K, Sayehmiri K et al. (2012) Antimicrobial resistance patterns and their encoding genes among Acinetobacter baumannii strains isolated from burned patients. Burns. 38:1198-203.

Chaudhary M, Payasi A (2012). Molecular Characterization and Antimicrobial Susceptibility Study of Acinetobacter baumannii Clinical Isolates 
from Middle East, African and Indian Patients. J Proteomics Bioinf .5: 265-9.

CLSI, (Clinical \& Laboratory Standards institute). Performance standard for antimicrobial susceptibility testing (2013). Seventeenth informational supplement .M100-S23. 33 (1).

Daef EA, Mohamed IS, Ahmed AS, Elsherbiny NM, Sayed IM (2012). Evaluation of different phenotypic assays for the detection of metallo- $\beta$-lactamase production in carbapenem susceptible and resistant Acinetobacter baumannii isolates. J Americ Sci .8:292-9.

Dent LL, Marshall DR, Pratap S, Hulette RB (2010). Multidrug resistant Acinetobacter baumannii: a descriptive study in a city hospital. BMC Infect Dis .10:196.

Drieux L, Brossier F, Sougakoff W, Jarlier V (2008). Phenotypic detection of extended-spectrum betalactamase production in Enterobacteriaceae: review and bench guide. Clin Microbiol Infect. 11:90-103.

Gupta V, Datta P, Chander J (2006). Prevalence of metallo- $\beta$-lactamase (MBL) producing Pseudomonas spp. and Acinetobacter spp. in a tertiary care hospital in India. J Infect.52: 311-14.

Haldorsen BC (2011). Aminoglycoside resistance in clinical Gram-negative isolates from Norway.M.Sc. Thesis in medical biology. Norway. University of Tromso.

Hassan A, Usman J, Kaleem F, Khan A, Hussain Z (2010). In vitro activity of aminoglycosides, Blactam-B-lactamases inhibitor combinations and tetracyclines against multi-drug resistant Acinetobacter baumannii, isolated from a tertiary care hospital. J Microbiol Antimicrob .2:47-50.

Huang J, Ye M, Jia X, Yu F. Wang M (2012). Coexistence of armA and genes encoding aminoglycoside-modifying enzymes in Acinetobacter baumannii. Afr J Microbiol Res. 6: 5325-30.

Hussein H, Al-Mathkhury H, Sabbah M (2013). Imipenem-Resistant Acinetobacter baumannii isolated from patients and hospitals environment in Baghdad. Iraqi J Sci. 54:803-812.

Jaggi N, Sissodia P, Sharma L (2012). Acinetobacter baumannii isolates in a tertiary care hospital: Antimicrobial resistance and clinical significance. $\mathrm{J}$ Microbiol Infect Dis. 2: 57-63.

Karlowsky JA, Draghi DC, Jones ME, Thornsberry C, Friedland IR, Sahm, DF (2003). Surveillance for antimicrobial susceptibility among clinical isolates of Pseudomonas aeruginosa and Acinetobacter baumannii from hospitalized patients in the United States, 1998 to 2001. Antimicrob Agents Chemother .47:1681-8.

Koo SH, Kwon KC, Cho HH, Sung JY (2010). Genetic Basis of Multidrug-resistant Acinetobacter baumannii Clinical Isolates from Three University Hospitals in Chungcheong Province, Korea. Korean J Lab Med. 30: 498-506.

Kumar AV, Pillai VS, Dinesh KR, Karim S (2011). The phenotypic detection of carbapenemase in the meropenem resistant Acinetobacter calcoaceticusbaumannii complex in a tertiary care hospital in south India. JCDR. 5:223-6.

Livermore DM (2003). The threat from the pink corner. Ann Med. 35:226-34.

Moniri R, Farahani RK, Shajari G, Shirazi MN, Ghasemi, A (2010). Molecular Epidemiology of Aminoglycosides Resistance in Acinetobacter Spp. with Emergence of Multidrug-Resistant Strains. Iranian J Publ Health. 39:63-8.

Ndegwa DW, Budambula NLM, Kariuki G, Kiiru JN (2012).Aminoglycoside modifying enzymes detected in strains of Escherichia, Klebsiella, Pseudomonas and Acinetobacter implicated in invasive infections in Nairobi, Kenya. Centre for Microbiology. Kenya Medical Research Institute. Nairobi. Kenya.

Nordmann P (2004)..Acinetobacter baumannii, the nosocomial pathogen par excellence. Pathol Biol Paris. 52:301-303.

Oliveira FA, Paludo KS, Arend LN, Farah SM, Pedrosa FO, Souza EM, et al. (2011). Virulence characteristics and antimicrobial susceptibility of uropathogenic Escherichia coli strains. Genet Mol Res. 10:4114-25.

Ramirez MS, Tolmasky ME (2010).Aminoglycoside Modifying Enzymes. Drug Resist Updat. 13:151-71.

Ruppé E, Hem S, Lath S, Gautier V, Ariey F, Sarthou J, et al. ( 2009).CTX-M $\beta$-Lactamases in Escherichia coli from community-acquired Urinary Tract Infections, Cambodia. EID journal. 15:741-8.

Seward RJ, Lambert T, Towner KJ (1998). Molecular epidemiology of aminoglycoside resistance in Acinetobacter spp. J Med Microbiol. 47:455-62.

Shi WF, Jiang JP, Mi ZH (2005).Relationship between antimicrobial resistance and aminoglycoside modifying enzyme gene expressions in Acinetobacter Baumannii. Chin Med J. 118:141-5.

Taitt CR, Leski TA, Stockelman MG, Craft DW, Zurawski DV, Kirkup BC et al. (2014). Antimicrobial resistance determinants in Acinetobacter baumannii isolates taken from military treatment facilities, Antimicrob Agents Chemother. 58: 767-81.

Trivedi GR, Soni ST, Vegad MM, Yadav KS (2012). Occurrence and Detection of Extended Spectrum Blactamase and AmpC B-lactamase in Clinical Isolates of Pseudomonas aeruginosa and Acinetobacter baumanii by Inhibitor based Method. Int J Microbiol Res. 4:299-301.

Turton JF, Kaufmann ME, Glover J, Coelho JM, Warner M, Pike R et al. (2005). Detection and typing of integrons in epidemic strains of Acinetobacter baumannii found in the United Kingdom. J Clin Microbiol. 43:3074-82.

Uma KR, Srinivasa RR, Suchismita $S$, Shashikala $P$, Kanungo R, Jayachandran et al. (2009). Phenotypic and genotypic assays for detecting the prevalence of metallo-b-lactamases in the clinical isolates of Acinetobacter baumannii from a south Indian tertiary care hospital. J Med Microbiol. 58:430-35. 
Vaziri F, Peerayeh SN, Nejad QB, Farhadian A (2011). The prevalence of aminoglycoside modifying enzyme genes (aac (69)-I, aac (69)-II, ant (20)-I, aph (39)-VI) in Pseudomonas aeruginosa. Clinics Sci. 66:1519-22.
Xu J, Wu H, Li J, Zhou Q (2012). Antimicrobial Resistance Surveillance of Acinetobacter Baumannii Isolated from a Teaching Hospital. FITMSEI. 14:37981.

\footnotetext{
Cite this Article: Israa MSA, Marwah HA, Hadeel KM, 2015. Detection of aminoglycoside modifying enzymes and $\beta$ lactamases in Acinetobacter baumannii isolated from hospitalized Iraqi patients. Greener Journal of Biological Sciences, 5(1): 010-019. http://doi.org/10.15580/GJBS.2015.1.012115007.
} 